\title{
A study on efficiency of e-banking outsourcing in Iran
}

\author{
Hassan Ghodrati $^{\mathrm{a}}$ and Abdorreza Sharifihosseini ${ }^{\mathrm{b} *}$
}

${ }^{a}$ Department of Accounting \& Management, Kashan Branch, Islamic Azad University, Kashan, Iran

${ }^{b}$ Department of Management, Electronic Branch, Islamic Azad University, Tehran, Iran

\section{CHRONICLE ABSTRACT}

Article history:

Received February 18, 2013

Received in revised format

8 May 2013

Accepted May 102013

Available online

May 122013

Keywords:

OMBOK structure

Outsourcing

E-banking

\begin{abstract}
This paper evaluates the outsourcing procedures' conformity of E-banking services in some Iranian private banks according to the OMBOK structure. The insight on the outsourcing as a supportive source for the strategies of an organization is increasing and outsourcing is not being looked at as an element for reducing the organization's costs anymore. Therefore, there is an increasing trend in banking sector towards employing the outsourcing, as an effective response to the environment and attracting customers. This paper attempt to find out how outsourcing procedures of e-baking services in private banks is corresponded with the framework of this standard. The study considers five primary dimensions consisting of infrastructure, operation management, business, customer relations and technology among private banks across the country based on OMBOK model. The study selects 90 experts out of 100 people in the field of E-banking as sample study and distributes some questionnaires among them and the questionnaire is analyzed using Kruskal-Wallis test.

According to the achieved results, out of the five domains of OMBOK structure including infrastructure, business, technology, customer relations and operation management, the outsourcing procedures of the e-banking services in Iran's private banks does not correspond in two domains of infrastructure and business, but corresponded in other domains.
\end{abstract}

\section{Introduction}

During the past few years, we have seen tremendous effort on outsourcing low value added activates in different industries. Managers have taken important steps towards breaking down their value-chain by outsourcing some major activities to other external providers gradually. Issues such an increase in competitive pressures, business difficulties, resource limitation, technological complicacy, jobs have become more specialized. In addition, environmental mutations' speed, lack of trust in future, costs increase, some organizations being overly big, especially in the public sector, as well as legal restrictions have created strong motivation among people to reconsider their managerial patterns and proceed to new strategies to gain competitive advantages in the current business world. 
The primary objective of outsourcing is to focus on the major qualifications and use sources from outside the organization to perform non-value added activities or to make it sound more specialized. On this ground, in order to provide the possibility of an efficient accountability together with a desired level providing necessary services for customers and to make institutions more powerful in responding to the various requests today, outsourcing has been employed based on leading institutions as an effective tool. Moreover, outsourcing is being utilized extensively in banking industry and when many information technologies require e-banking. E-banking services, indeed, are always established based on information technology and they are developed based on knowledge.

From the beginning, when information technology was introduced in banks, they attempted to establish the informatics office via the outsourcing technique. However, there was an increasing trend on using different features of e-banking, which indicates that banks must execute part of their activities inside their organizations. In fact, e-banking knowledge domain became more specialized, advent of markets and universal competitors and new competitive strategies, which have constructed upon quality, speed and cooperation agreements, universalization, decentralization, quality management, concurrent engineering, merges and properties, strategic agreements, pivotal capabilities, manpower diversity, environmental requirements, information and communication revolution.

It is evident that specialization and limiting the tasks range in development will be possible only if part of these tasks be relegated to the outside of the system which will be a preface to a new subject namely "outsourcing". And banks' managers considered this outsourcing in the long run. Even in past five years, some of the leading managers in Iran's banking industry proceeded to do the operational process of service providing. It means that the contractor company undertook all the necessary tasks for offering services on behalf of the bank and bank merely plays its role as a control unit. With this change in managerial patterns, they proceeded to the strategy of focusing on major qualifications and delegating task implementation to the outside of the organization. Outsourcing is not just an element for reducing the organization's costs, yet it plays an essential role in management in organizations. The aim of this paper is to evaluate the effects of e-baking services outsourcing processes in private banks with the specified OMBOK structure. We also try to identify the weakness and strength of ebanking services outsourcing processes. We also offer solutions for an improvement in e-banking services outsourcing processes and finally fulfilling the practical purpose of pathology of the current situation of outsourcing in the electronic banking domain.

\section{Literature review}

Palvia (1995) proposed an issue pertinent to the experience of a bank on outsourcing and took advantage of two people's points of views, one pro and the other against, both were engaged closely in an outsourcing process. He further concluded that it would be better to outsource an activity or a task completely and avoid breaking it down to various parts or even to other contractors. Moreover, the criteria of outsourcing must only be the costs relative to activities. It identified cost management, accountability and flexibility, focusing on the main business and finally proper accessibility to new technologies as the outsourcing advantages and similarly plummeting of staff's spirits due to the uncertainty in jobs, complicacy of blending (staffs and) contractors' jobs' results and the strategic dependency on contractors as outsourcing disadvantages. Misra (2004) tried to offer parameters for measuring outsourcing's success rate in information technology industry. He concluded that the success of an outsourcing project depends on the success of three parties in this activity i.e. that is the outsourcer organization and the organization under outsourcing and the end user who will receive these items or services. Besides, proposing a framework for the evaluating parameters, he further attempted to offer motivational approaches to carry out some improvements in the outsourcing performance. Gonzales et al. (2005) classified the outsourcing literatures in Table 1 and Table 2 as follows, 
Table 1

The chronological classification of outsourcing researches

\begin{tabular}{lcccc}
\hline & Until $1995(\%)$ & $1996-2000(\%)$ & Since 2001 (\%) & Total (\%) \\
\hline Total theoretical & $17 ; 13.0$ & $12 ; 9.2$ & $19 ; 14.5$ & $48 ; 36.6$ \\
Conceptual & $4 ; 3.1$ & $1 ; 0.8$ & $2 ; 1.5$ & $7 ; 5.3$ \\
Illustrative & $8 ; 6.1$ & $3 ; 2.3$ & $9 ; 6.9$ & $20 ; 15.3$ \\
Applied-concept & $5 ; 3.8$ & $8 ; 6.1$ & $8 ; 6.1$ & $21 ; 16.0$ \\
\hline Total empirical & $18 ; 13.7$ & $28 ; 21.4$ & $37 ; 28.2$ & $83 ; 63.4$ \\
Case studies & $9 ; 6.9$ & $11 ; 8.4$ & $13 ; 9.9$ & $33 ; 25.2$ \\
Field studies & $8 ; 6.1$ & $11 ; 8.4$ & $18 ; 13.7$ & $37 ; 28.2$ \\
Case and field studies & $0 ; 0.0$ & $3 ; 2.3$ & $4 ; 3.1$ & $7 ; 5.3$ \\
Other empirical studies & $1 ; 0.8$ & $3 ; 2.3$ & $2 ; 1.5$ & $6 ; 4.6$ \\
\hline Total & $35 ; 26.7$ & $40 ; 30.5$ & $56 ; 42.7$ & $131 ; 100.0$ \\
\hline
\end{tabular}

Table 2

The Chronological and thematic classification of outsourcing researches

\begin{tabular}{lllll}
\hline & Until $1995(\%)$ & $1996-2000(\%)$ & Since 2001(\%) & Total (\%) \\
\hline perspective of the client & $44 ; 21.4$ & $31 ; 15.1$ & $25 ; 12.1$ & $100 ; 48.7$ \\
Success factors & $0 ; 0.0$ & $4 ; 1.9$ & $4 ; 1.9$ & $8 ; 3.9$ \\
Reasons & $15 ; 7.3$ & $9 ; 4.3$ & $4 ; 1.9$ & $28 ; 13.6$ \\
Risks & $8 ; 3.9$ & $4 ; 1.9$ & $9 ; 4.3$ & $21 ; 10.2$ \\
Decision-making & $8 ; 3.9$ & $6 ; 2.9$ & $5 ; 2.4$ & $19 ; 9.2$ \\
General view & $13 ; 6.3$ & $8 ; 3.9$ & $3 ; 1.4$ & $24 ; 11.7$ \\
\hline perspective of the provider & $4 ; 1.9$ & $8 ; 3.9$ & $21 ; 10.2$ & $33 ; 16.0$ \\
ASP & $0 ; 0.0$ & $0 ; 0.0$ & $12 ; 5.8$ & $12 ; 5.8$ \\
Global outsourcing & $3 ; 1.4$ & $3 ; 1.4$ & $7 ; 3.4$ & $13 ; 6.3$ \\
Providers & $1 ; 0.4$ & $5 ; 2.4$ & $2 ; 0.9$ & $8 ; 3.9$ \\
\hline perspective of the relationship & $8 ; 3.9$ & $12 ; 5.8$ & $15 ; 7.3$ & $35 ; 17.0$ \\
Contract & $4 ; 1.9$ & $6 ; 2.9$ & $4 ; 1.9$ & $14 ; 6.8$ \\
Assessment, price & $1 ; 0.4$ & $2 ; 0.9$ & $2 ; 0.9$ & $4 ; 1.9$ \\
Client-provider relationship & $3 ; 1.4$ & $4 ; 1.9$ & $9 ; 4.3$ & $16 ; 7.8$ \\
\hline perspective of economic theories & $5 ; 2.4$ & $4 ; 1.9$ & $10 ; 4.8$ & $19 ; 9.2$ \\
Agency theory & $1 ; 0.4$ & $0 ; 0.0$ & $2 ; 0.9$ & $3 ; 1.4$ \\
\hline Transaction cost theory & $3 ; 1.4$ & $3 ; 1.4$ & $6 ; 2.9$ & $12 ; 5.8$ \\
\hline Other theories & $1 ; 0.4$ & $1 ; 0.4$ & $2 ; 0.9$ & $4 ; 1.9$ \\
\hline Others & $1 ; 0.4$ & $6 ; 2.9$ & $11 ; 5.3$ & $18 ; 8.7$ \\
\hline Nationality & $0 ; 0.0$ & $1 ; 0.4$ & $3 ; 1.4$ & $4 ; 1.9$ \\
IS staff & $1 ; 0.4$ & $2 ; 0.9$ & $5 ; 2.4$ & $8 ; 3.9$ \\
Industry & $0 ; 0.0$ & $3 ; 1.4$ & $3 ; 1.4$ & $6 ; 2.9$ \\
\hline Total & $62 ; 30.2$ & $61 ; 29.7$ & $205 ; 100.0$ \\
\hline
\end{tabular}

Lacity et al. (2009) studied the evolution trajectory of the current issue via the scrutiny of 191 papers published over the period 1990-2009 on outsourcing within information technology domain and attempted to develop concepts such as business procedures' outsourcing (BPO), software service providing (ASP) and outsourcing to developing countries (Offshoring). They finally concluded that outsourcing developed from the equipment production domain to service providing domain and with the increasing spread of outsourcing, it is necessary to create a harmony between the outsourcing strategies and business strategies. According to KPMG (2010), foreign banks mainly prefer not to use outsourcing in order to achieve prosperity in the field of customers' access channels to electronic banks. Moghimi (2007) evaluated the knowledge rate of Tehran's ISPs from the outsourcing advantages, risk rate or advantages and concluded that there was a relationship between company size, annual sales and a history of ISP with the risk rate or advantages achieved from outsourcing. Salehi (2008) evaluated the effective factors on the outsourcing prosperity of research papers and information technology development. Asooshe et al. (2009) identified the rate of outsourcing risks for information systems and surveyed the reasons for information systems' outsourcing and finally 
identified and extracted the effective factors behind the prosperity of the remaining risks' management.

\section{Research hypotheses}

\section{Main Hypothesis}

There is a relationship between the outsourcing processes of E-banking service in private banks with OMBOK structure.

\section{Other hypotheses}

1. There is a correlation between the outsourcing processes of E-banking service in private banks with OMBOK structure in infrastructure domain.

2. There is a correlation between the outsourcing processes of E-banking service in private banks with OMBOK structure in operation domain.

3. There is a correlation between the outsourcing processes of E-banking service in private banks with OMBOK structure in business domain.

4. There is a correlation between the outsourcing processes of E-banking service in private banks with OMBOK structure in technology domain.

5. There is a correlation between the outsourcing processes of E-banking service in private banks with OMBOK structure in customer relations domain.

\section{Research methodology}

The general procedure employed in this paper is practical in terms of the models and the current theories. The inference method in this paper is a-priori due to the application of a descriptive random sample when describing typical observations and generalizing the results to the a-priori statistical universe.

\subsection{Statistical sample and community}

In this research, the statistical universe consists of experts, agents and employees of private banks in Tehran (Iran). First, 10 people were selected randomly out of these experts and based on the Cronbakh Alpha was equal to 93\%, the veracity and accuracy of questionnaire were evaluated. Next, using Cochran formula, the statistical sample's volume was determined and questionnaires were distributed among some people of this statistical universe via a simple random method. From this count, 90 valid questionnaires were returned.

\subsection{Data Collection Tools}

In this research, in order to collect the research literature from the library studies and internet searches, an on-site evaluation in the research domain using a questionnaire was conducted. The first part of this questionnaire contains demographic questions or respondents' attributes and the second part gives shelter to the research's major questions. The research's major questions were designed with a 1-to-9 option format in which 1 indicates the lowest degree of influence or importance and 9 indicates the highest degree of importance.

\subsection{Data Analyses Methods}

1. Descriptive statistics methods such as measuring the statistical parameters mean value and variance, frequency distribution table and charts for describing data. 
2. The variable distribution normalcy test as a default for analyzing the relationships between variables using the Kolmogorov-Smirnov test.

3. Correlation analysis for determining the relationships between variables. In the cases of variables' distribution normalcy, the Pierson's criteria and in other cases, the Spearman correlation ratios were used.

4. The concordance analysis of opinions based on the variance analysis in order to evaluate the impact of respondents' attributes on their comments' type.

\subsection{The research model}

The current research model is based on Outsource Management Body of Knowledge structure. The OMBOK structure has 11 domains with 5 main divisions like the following:1) Outsourcing infrastructure ,2) Technology , 3) Operations ,(including Communications, Project management and planning, Quality controls), 4) Business management (including Security and Internal controls, staff, professionalism). Fig. 1 illustrates the relationships among these 5 divisions.

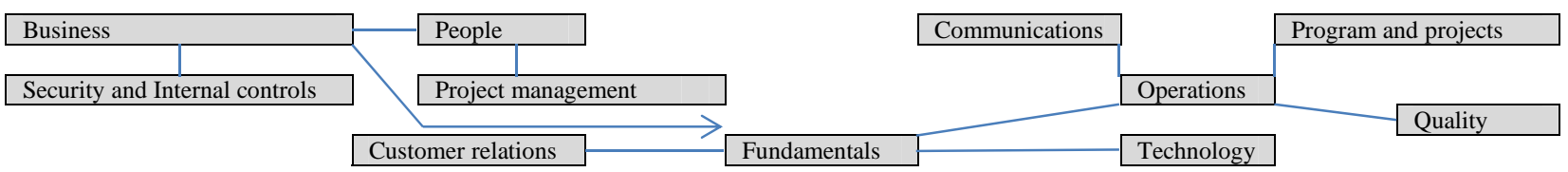

Fig. 1. OMBOK Standard Criteria

\section{Findings}

The reported statistics includes indices and central criteria such as the employed mean value in this research.

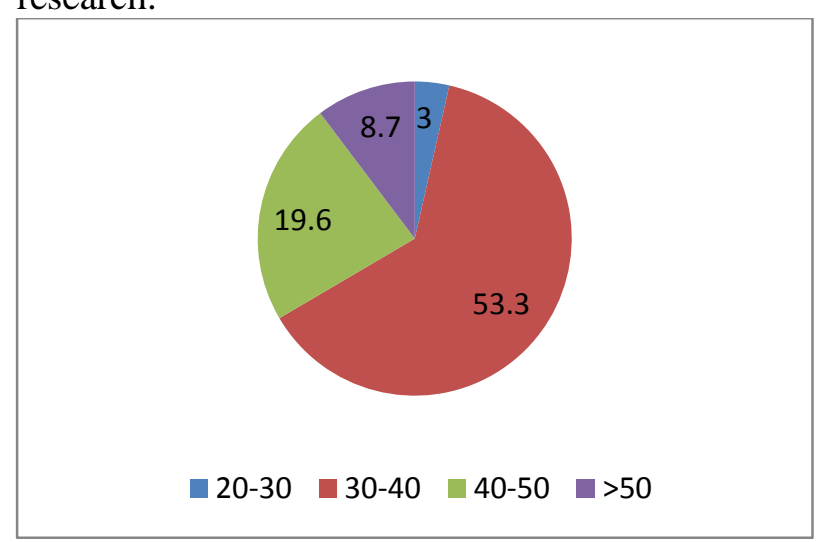

Fig. 2. Distribution of participants’ age

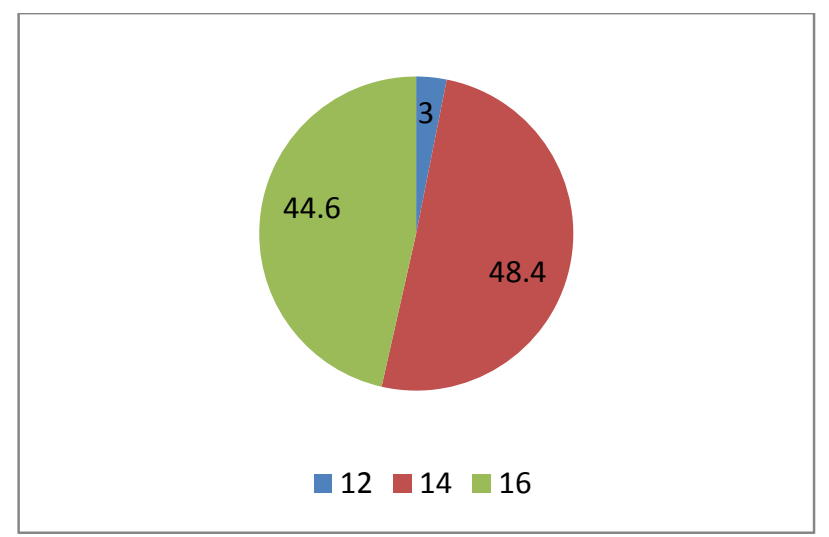

Fig. 2. Distribution of participants' educations

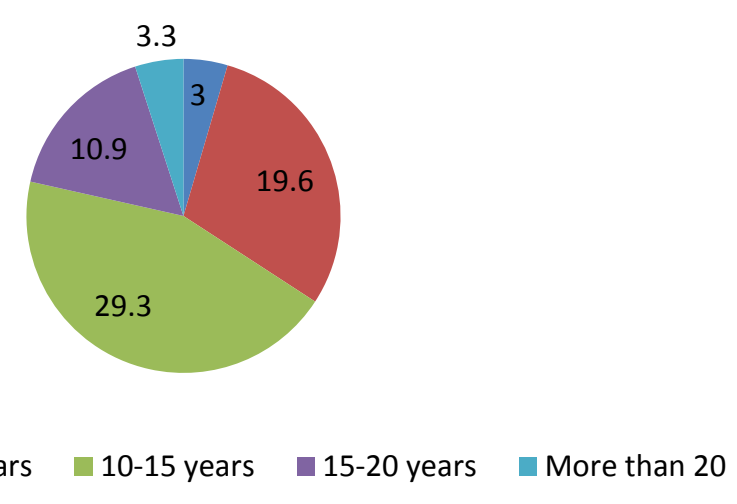

Fig. 4. Distribution of participants' years of experiences 
In chart 6 each dimension's mean value was indicated and having an eye on the fact that the main variable of the OMBOK model has a normal distribution, the T-student parametric test was utilized. The unilateral T-student test could be as follows:

Table 3

The results of t-student

Test Value $=5$

t df Sig. (2-tailed) Mean Difference 95\% Confidence Interval of the Difference Upper

\begin{tabular}{lcccccc}
$\begin{array}{l}\text { Infrastructure } \\
\text { variable }\end{array}$ & -2.436 & 89 & 0.12 & -.39769 & -.7221 & -.0733 \\
$\begin{array}{l}\text { Operation } \\
\text { management }\end{array}$ & 1.006 & 89 & 0.17 & .17290 & -.1687 & .5145 \\
$\begin{array}{l}\text { Business } \\
\begin{array}{l}\text { Customer- } \\
\text { orientation }\end{array}\end{array}$ & -.986 & 89 & 0.27 & -.18605 & -.5611 & .1890 \\
\hline
\end{tabular}

The results of Table 3 indicate that three components of infrastructure variable, operation management and business do not represent meaningful impact but customer orientation has meaningful impact.

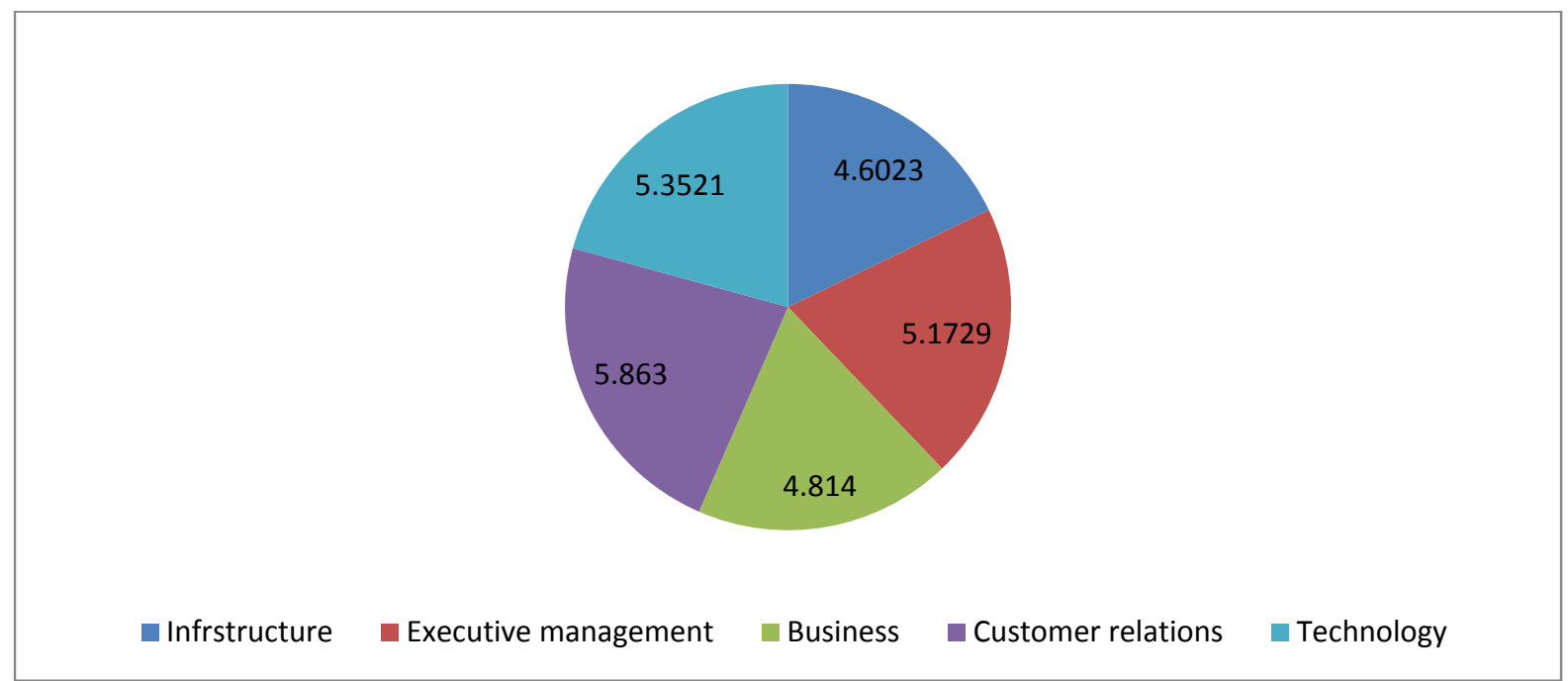

Fig. 5. The mean values of OMBOK model's dimensions

Fig. 5 demonstrates the mean values of OMBOK model's dimensions. As we can observe from the results of Fig. 5, Customer relationship receives the highest rank followed by infrastructure and executive management. We now look at how respondents think of each of the variable indices such as infrastructure, operational, business, customer relations and technology in private E-banking throughout the country. We employ the proportion's nonparametric test due to the infrastructure's variable do not indicate to have a normal distribution. In this test, answers were classified into two categories of less than the Likert spectrum average (the value 5) and more than the Likert spectrum average (the value 5) and it will be studied that to what extent the E-banking services outsourcing in Iran's private banks with an OMBOK structure had an accordance in infrastructure domain (more than $50 \%)$. 
Table 4

The infrastructure's variable proportion test results

\begin{tabular}{|c|c|c|c|c|c|c|c|}
\hline \multicolumn{2}{|c|}{ Variables and indices } & category & $\begin{array}{c}\text { Observed } \\
\text { number }\end{array}$ & $\begin{array}{l}\text { Observed } \\
\text { probability }\end{array}$ & $\begin{array}{l}\text { Meaningfulness } \\
\text { level }\end{array}$ & $\begin{array}{l}\text { Error } \\
\text { value }\end{array}$ & Test result \\
\hline \multirow{3}{*}{$\frac{\stackrel{\varrho}{\Xi}}{\text { 莺 }}$} & Cultural procurement & $\begin{array}{c}<=5 \\
>5 \\
\text { Total }\end{array}$ & $\begin{array}{l}60 \\
30 \\
90\end{array}$ & $\begin{array}{c}.67 \\
.33 \\
1.00\end{array}$ & .002 & 0.05 & incompliance \\
\hline & $\begin{array}{l}\text { Having cultural } \\
\text { variety }\end{array}$ & $\begin{array}{c}<=5 \\
>5 \\
\text { Total }\end{array}$ & $\begin{array}{l}77 \\
13 \\
90\end{array}$ & $\begin{array}{c}.86 \\
.14 \\
1.00\end{array}$ & .000 & 0.05 & incompliance \\
\hline & $\begin{array}{l}\text { Having cultural } \\
\text { intelligence }\end{array}$ & $\begin{array}{c}<=5 \\
>5 \\
\text { Total }\end{array}$ & $\begin{array}{l}59 \\
31 \\
90\end{array}$ & $\begin{array}{c}.66 \\
.34 \\
1.00\end{array}$ & .004 & 0.05 & incompliance \\
\hline \multirow{4}{*}{ 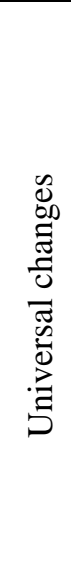 } & $\begin{array}{l}\text { Procedures' } \\
\text { outsourcing }\end{array}$ & $\begin{array}{c}<=5 \\
>5 \\
\text { Total }\end{array}$ & $\begin{array}{l}61 \\
29 \\
90\end{array}$ & $\begin{array}{c}.68 \\
.32 \\
1.00\end{array}$ & .001 & 0.05 & incompliance \\
\hline & $\begin{array}{c}\text { Managers' } \\
\text { perspective towards } \\
\text { changing rules }\end{array}$ & $\begin{array}{l}<=5 \\
>5 \\
\text { Total }\end{array}$ & $\begin{array}{l}53 \\
37 \\
90\end{array}$ & $\begin{array}{c}.59 \\
.41 \\
1.00\end{array}$ & 0.013 & 0.05 & incompliance \\
\hline & $\begin{array}{l}\text { Top-managers' } \\
\text { perspective towards } \\
\text { new styles in } \\
\text { banking }\end{array}$ & $\begin{array}{l}<=5 \\
>5 \\
\text { Total }\end{array}$ & $\begin{array}{l}40 \\
50 \\
90\end{array}$ & $\begin{array}{c}.44 \\
.56 \\
1.00\end{array}$ & .343 & 0.05 & compliance \\
\hline & $\begin{array}{l}\text { Top-manager's } \\
\text { ability }\end{array}$ & $\begin{array}{l}<=5 \\
>5 \\
\text { total }\end{array}$ & $\begin{array}{l}42 \\
48 \\
90\end{array}$ & $\begin{array}{c}.47 \\
.53 \\
1.00\end{array}$ & .598 & 0.05 & compliance \\
\hline
\end{tabular}

As we can observe from Table 4, the components of culture are statistically significant. In terms of universal changes, two components, procedures' outsourcing and managers' perspective toward changing rules were statistically significance but top-managers' perspective towards new styles in banking and top-managers' ability were not statistically significance.

Table 5

Customer relations

\begin{tabular}{cccccc}
\hline index & category & $\begin{array}{c}\text { Observed } \\
\text { number }\end{array}$ & $\begin{array}{c}\text { Observed } \\
\text { probability }\end{array}$ & $\begin{array}{c}\text { Meaningfulness } \\
\text { level }\end{array}$ & Test result \\
\hline Customer relation and & $<=5$ & 28 & .31 & & \\
satisfaction & $>5$ & 62 & .69 & .067 & compliance \\
& Total & 90 & 1.00 & & \\
Measuring deliverable & $<=5$ & 35 & .39 & & \\
services & $>5$ & 55 & .61 & .075 & compliance \\
& Total & 90 & 1.00 & & \\
Managing events and & $<=5$ & 35 & .39 & & compliance \\
problems & $>5$ & 55 & .61 & .085 & \\
\hline
\end{tabular}


Table 6

Technology

\begin{tabular}{|c|c|c|c|c|c|c|}
\hline \multicolumn{3}{|c|}{ index } & \multirow{3}{*}{$\begin{array}{c}\text { Observed } \\
\text { number }\end{array}$} & \multirow{3}{*}{$\begin{array}{c}\begin{array}{c}\text { Observed } \\
\text { number's } \\
\text { probability }\end{array} \\
.43\end{array}$} & \multirow{2}{*}{$\begin{array}{l}\text { Meaningfulness } \\
\text { level }\end{array}$} & \multirow{2}{*}{ Test result } \\
\hline & & category & & & & \\
\hline \multirow[t]{8}{*}{ Variable } & \multirow{3}{*}{ Technology } & $<=5$ & & & \multirow{3}{*}{.203} & \multirow[t]{3}{*}{ compliance } \\
\hline & & $>5$ & 51 & .57 & & \\
\hline & & Total & 89 & 1.00 & & \\
\hline & \multirow{3}{*}{ Using new technology } & $<=5$ & 37 & .42 & & \multirow[t]{3}{*}{ compliance } \\
\hline & & $>5$ & 52 & .58 & .137 & \\
\hline & & Total & 89 & 1.00 & & \\
\hline & \multirow[b]{3}{*}{$\begin{array}{l}\text { Investment in } \\
\text { technology part }\end{array}$} & $<=5$ & 44 & .49 & & \multirow[t]{3}{*}{ compliance } \\
\hline & & $>5$ & 45 & .51 & .279 & \\
\hline \multirow{4}{*}{ Index } & & Total & 89 & 1.00 & & \\
\hline & \multirow{3}{*}{$\begin{array}{l}\text { Technological gap } \\
\text { inside the organization }\end{array}$} & \multirow{3}{*}{$<=5$} & 39 & .44 & \multirow{3}{*}{.289} & \multirow[t]{3}{*}{ compliance } \\
\hline & & & 50 & .56 & & \\
\hline & & & 89 & 1.00 & & \\
\hline
\end{tabular}

Now we study the research results and comments' concordance via the Kruskal-Wallis test (regarding the respondent people's years of experience) and we want their opinion about that according to the years of experience in E-banking domain in each of the infrastructure domain's variables of Outsourcing activities of E-banking services with the OMBOK structure. The results are shown in Table 7.

Table 7

The results of Kruskal-Wallis test

\begin{tabular}{cccccc}
\hline & $\begin{array}{c}\text { Operation } \\
\text { management }\end{array}$ & business & $\begin{array}{c}\text { Customer } \\
\text { relation }\end{array}$ & Technology & infrastructure \\
\hline Chi-Square & 9.406 & 3.773 & 10.721 & 4.777 & 21.936 \\
df & 4 & 4 & 4 & 4 & 4 \\
Asymp. Sig. & .052 & .438 & .030 & .311 & .000 \\
\hline Test result & $\begin{array}{c}\text { Similarity of } \\
\text { comments }\end{array}$ & $\begin{array}{c}\text { Similarity of } \\
\text { comments }\end{array}$ & $\begin{array}{c}\text { Difference in } \\
\text { comments }\end{array}$ & $\begin{array}{c}\text { Similarity of } \\
\text { comments }\end{array}$ & $\begin{array}{c}\text { Difference in } \\
\text { comments }\end{array}$ \\
\hline
\end{tabular}

As we can observe from the results of Table 8, for those variables with a meaningful level less than the error value of 0.05 , the zero presupposition will be rejected when the level of significance is 0.05 . This rejection applies to the infrastructure variable and the customer relations variable and as a result we can say that in this variable, people's comments regarding the years of experience in E-banking domains is different and the highest rate goes to those people with 15 to 40 years of experience. Comment's concordance was determined via the Kruskal-Wallis test (with regards to the respondents' education) 
Table 8

Indicates the rate with regards to the difference between comments

\begin{tabular}{|c|c|c|c|}
\hline Variable & Background & number & Rank average \\
\hline \multirow{6}{*}{ Operation management } & under 5 years & 32 & 42.11 \\
\hline & 5-10 years & 18 & 56.31 \\
\hline & $10-15$ years & 27 & 36.63 \\
\hline & $15-20$ years & 10 & 57.75 \\
\hline & 20 years & 3 & 55.83 \\
\hline & total & 90 & \\
\hline \multirow{6}{*}{ Business } & under 5 years & 32 & 41.34 \\
\hline & 5-10 years & 18 & 51.97 \\
\hline & $10-15$ years & 27 & 42.22 \\
\hline & $15-20$ years & 10 & 55.30 \\
\hline & 20 years & 3 & 47.83 \\
\hline & total & 90 & \\
\hline \multirow{6}{*}{ Customer relation } & under 5 years & 32 & 43.14 \\
\hline & 5-10 years & 18 & 55.08 \\
\hline & $10-15$ years & 27 & 35.19 \\
\hline & $15-20$ years & 10 & 60.00 \\
\hline & 20 years & 3 & 57.67 \\
\hline & total & 90 & \\
\hline \multirow{6}{*}{ Technology } & under 5 years & 32 & 46.19 \\
\hline & 5-10 years & 17 & 53.35 \\
\hline & $10-15$ years & 27 & 37.56 \\
\hline & $15-20$ years & 10 & 49.65 \\
\hline & 20 years & 3 & 36.50 \\
\hline & total & 89 & \\
\hline \multirow{6}{*}{ Infrastructure } & under 5 years & 32 & 31.98 \\
\hline & 5-10 years & 18 & 60.28 \\
\hline & $10-15$ years & 27 & 43.17 \\
\hline & $15-20$ years & 10 & 67.90 \\
\hline & 20 years & 3 & 47.33 \\
\hline & total & 90 & \\
\hline
\end{tabular}

Table 9

Kruskal-Wallis test

\begin{tabular}{cccccc}
\hline & $\begin{array}{c}\text { Operation } \\
\text { management }\end{array}$ & business & $\begin{array}{c}\text { Customer } \\
\text { relation }\end{array}$ & Technology & infrastructure \\
\hline Chi-Square & 3.152 & 3.460 & 4.556 & 4.404 & 2.639 \\
df & 2 & 2 & 2 & 2 & 2 \\
Asymp. Sig. & .207 & .177 & .102 & .111 & .267 \\
\hline
\end{tabular}


As we can observe from the results of Table 9, for those variables with a meaningful level less than the error value of 0.05 , the zero presupposition will be rejected in the meaningful level of 0.05 which will be approved with regards to all other variables according to the zero presupposition tests. Also, there's no difference in comments according to education.

\section{Conclusion}

Based on the conducted study via a test, the ratio of pros in a standard dimension is consistent with three dimensions of customer relations, technology and operational management with an OMBOK structure. However, there was not any relationship between two dimensions of business and infrastructure, which indicates that the standard structure in private banks throughout the country focused more on the infrastructure domain and business domain for outsourcing E-banking services. In order to study more, the importance degree of each of these standard indices was evaluated according to a survey conducted on experts in an outsourcing domain and was compared with the current status in private banks which can be seen in Fig. 6 .

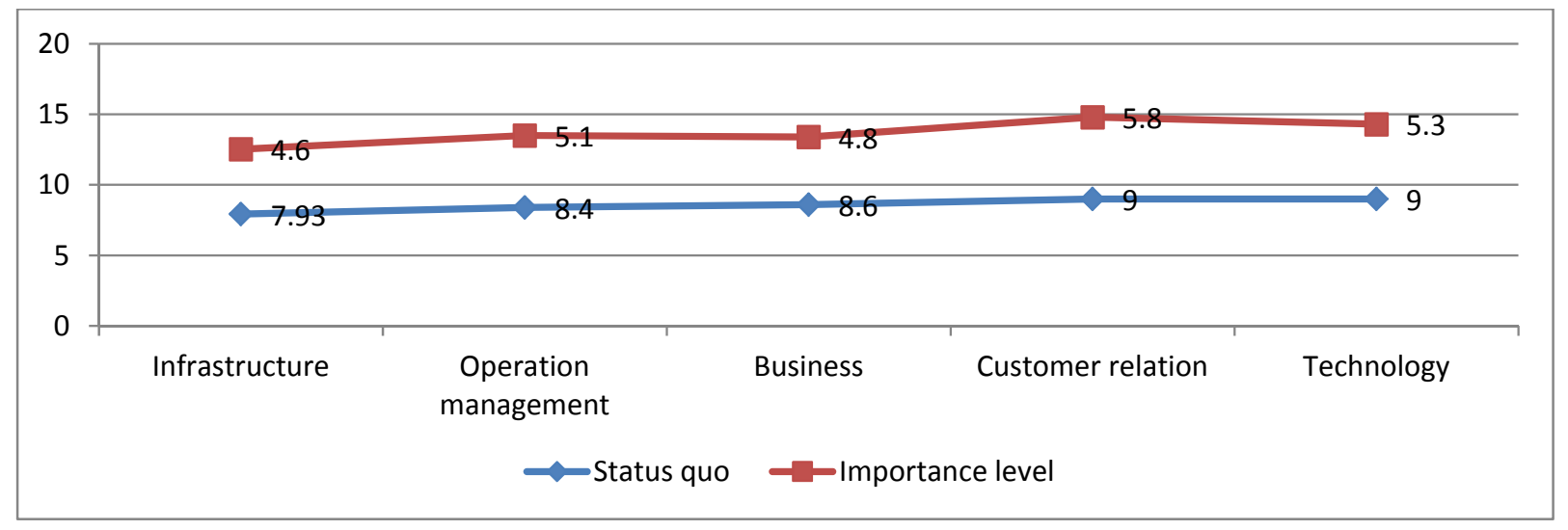

Fig. 6. The comparison between the as-is and to-be situation

Based on the research results, we can suggest training and teaching OMBOK structure and its effects and dimensions by managers and experts. Since this standard was introduced in banking outsourcing methods, we suggest that you administer teaching courses for getting to know the pre-mentioned standard for managers and experts. We suggest that the contractors' evaluation process be developed based on an OMBOK structure for outsourcing in E-banking domain. In order to grant the E-banking services' processes, we must collect processes for outsourcing in banks via the OMBOK structure.

\section{References}

Asousheh, A., Diavandari, A., Karami, A., \& Yazdani, H. (2009). Identifying CSFS in risk management OF Information systems outsourcing projects in Iranian commercial banks. Journal oF Information Technology Manamgement. 3.

Gonzalez, R., Gasco, J., \& Llopis, J. (2006). Information systems outsourcing: A literature analysis. Information \& Management, 43(7), 821-834.

KPMG. (2010). Banking System Survey. 15.

Lacity, M. C., Khan, S. A., \& Willcocks, L. P. (2009). A review of the IT outsourcing literature: Insights for practice. The Journal of Strategic Information Systems, 18(3), 130-146.

Misra, R. B. (2004). Global IT outsourcing: metrics for success of all parties. Journal of Information Technology Cases and Applications, 6(3), 21-34.

Palvia, P. C. (1995). A dialectic view of information systems outsourcing: pros and cons. Information \& Management, 29(5), 265-275.

Salehi (2008). Identifying Success Factors for Outsourcing IT Projects, Azahra Univ. 